\title{
Beauty in the Age of Empire
}

Columbia Studies in International and Global History

Studies of the Weatherhead East Asian Institute, Columbia University 


\section{Columbia Studies in International and Global History}

\section{CEMIL AYDIN, TIMOTHY NUNAN, AND DOMINIC SACHSENMAIER, SERIES EDITORS}

This series presents some of the finest and most innovative work coming out of the current landscapes of international and global historical scholarship. Grounded in empirical research, these titles transcend the usual area boundaries and address how history can help us understand contemporary problems, including poverty, inequality, power, political violence, and accountability beyond the nation-state. The series covers processes of flows, exchanges, and entanglements-and moments of blockage, friction, and fracture-not only between "the West" and "the Rest" but also among parts of what has variously been dubbed the "Third World" or the "Global South." Scholarship in international and global history remains indispensable for a better sense of current complex regional and global economic transformations. Such approaches are vital in understanding the making of our present world.

Cemil Aydin, The Politics of Anti-Westernism in Asia: Visions of World Order in Pan-Islamic and Pan-Asian Thought

Adam M. McKeown, Melancholy Order: Asian Migration and the Globalization of Borders

Patrick Manning, The African Diaspora: A History Through Culture

James Rodger Fleming, Fixing the Sky: The Checkered History of Weather and Climate Control

Steven Bryan, The Gold Standard at the Turn of the Twentieth Century: Rising Powers, Global Money, and the Age of Empire

Heonik Kwon, The Other Cold War

Samuel Moyn and Andrew Sartori, eds., Global Intellectual History

Alison Bashford, Global Population: History, Geopolitics, and Life on Earth

Adam Clulow, The Company and the Shogun: The Dutch Encounter with Tokugawa Japan

Richard W. Bulliet, The Wheel: Inventions and Reinventions

Simone M. Müller, Wiring the World: The Social and Cultural Creation of Global Telegraph Networks

Will Hanley, Identifying with Nationality: Europeans, Ottomans, and Egyptians in Alexandria

Perin E. Gürel, The Limits of Westernization: A Cultural History of America in Turkey

Dominic Sachsenmaier, Global Entanglements of a Man Who Never Traveled: A Seventeenth-Century Chinese Christian and His Conflicted Worlds

Perrin Selcer, The UN and the Postwar Origins of the Global Environment: From World Community to Spaceship Earth 


\section{Beauty in the \\ Age of Empire}

Japan, Egypt, and the Global

History of Aesthetic Education

RAJA ADAL

Columbia

University

Press

New York 
Columbia University Press

Publishers Since 1893

New York Chichester, West Sussex

cup.columbia.edu

Copyright @ 2019 Columbia University Press

All rights reserved

Library of Congress Cataloging-in-Publication Data

Names: Adal, Raja, author.

Title: Beauty in the age of empire : Japan, Egypt, and the global history of aesthetic education / Raja Adal.

Description: New York : Columbia University Press, [2019] |

Series: Columbia studies in international and global history | Includes

bibliographical references and index.

Identifiers: LCCN 2018060456 | ISBN 9780231191166 (cloth : alk. paper) |

ISBN 9780231549288 (e-book)

Subjects: LCSH: Arts-Study and teaching (Primary)-Japan. | Arts-Study and teaching (Primary)-Egypt. | Arts in education.

Classification: LCC NX384.A1 A33 2019| DDC 700.71-dc23

LC record available at https://lccn.loc.gov/2018060456

Columbia University Press books are printed on permanent and durable acid-free paper.

Printed in the United States of America

Cover image: Oisha san [The doctor], 1936, Kikuchi Tomijirō, first-year student in regular higher primary school (kōtōka ichinen, Yamagata ken Kitamurayama gun Nagatoro mura Nagatoro jinjō kōtō shōgakkō, currently Higashine shiritsu Nagatoro shōgakkō). Used with permission of the family of Kikuchi Tomijirō and Nagatoro shōgakkō sōga o kataru kai. 